\title{
Carbon Dioxide Emissions Monitoring in Romania in the Context of Greenhouse Gases Reduction
}

\author{
Avram Lazăr, Cristescu Tudora, Stoica Monica Emanuela \\ Drilling, Extraction and Transport of Hydrocarbons Department \\ Petroleum - Gas University of Ploiesti \\ Ploiesti, Romania \\ avram_lazar55@yahoo.com,cristescuteo@gmail.com,monicastoica20022002@yahoo.com
}

\begin{abstract}
The weather changes we are currently witnessing, characterised by dynamism and extreme phenomena, are the direct and indirect result of human activities which are determining the global atmosphere change in composition. The paperwork follows the evaluation and comparison of carbon dioxide emission coefficient in case of liquid oil fuels burning.

The calculus model used for the carbon dioxide emission coefficient evaluation has been developed based on mathematical models from specific publications. It was applied in the case study based on data from specific literature. The results obtained following the evaluation allowed certain comparisons in the field of carbon dioxide emissions in case of the complete burning of certain fluid hydrocarbons use in industry.
\end{abstract}

Keywords- carbon dioxide emission coefficient, oil, monitoring

\section{INTRODUCTION}

In Romania, the negative effects of extreme meteorological phenomena generated significant economic losses in agriculture and rural development, transportation, energy supplying and water management.

The greenhouse gases are: carbon dioxide, methane, nitrogen protoxide, hydrofluorinecarbons, petrofluorinecarbons and sulfide hexafluorine.

The greenhouse effect is determined by these gasses' selective absorption of the Earth's thermal radiation and its isotopic reemission in the extra atmospheric space and towards the Earth. The infrared radiation reissued towards the Earth contributes to the low atmosphere warming, including the Earth itself [9].

Due to the increasing concentrations of these gases, the greenhouse effect intensifies and the energy and system moisture transportation is disturbed, leading to imbalances in the climate system.

A $4^{\circ} \mathrm{C}$ increase in atmospheric temperature by the end of the century would have a considerable impact on climate change, which would produce a considerable damage in Romania. Consequently, GHG emission reduction and adaptation to climate changes are priorities for Romania [9].

Romania was the first country to ratify the Kyoto Protocol (KP) and has reduced GHG emissions by $50 \%$ by the end of the period 2008 - 2012, although Romania's contribution to global emissions is insignificant (only $0.3 \%$ of emissions of greenhouse world and less than $3 \%$ of total emissions from EU countries) [9].

By sectors of activity, GHG emissions in 2011, are presented according to [8] in figure 1, the largest producer of the emissions being the energy sector.

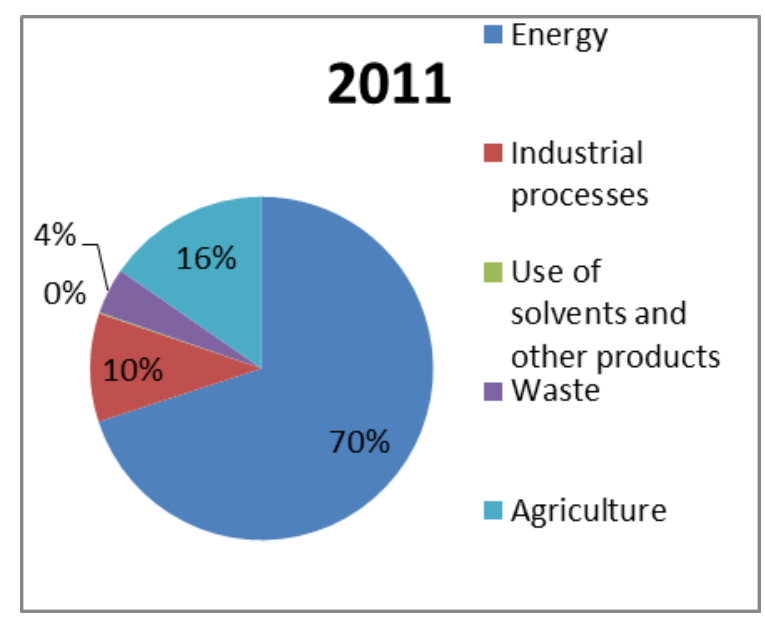

Fig. 1. Greenhouse emissions by field of activity

By 2020, Romania will have also to meet the targets of "2020-20" within the "Energy \& Climate Package" of the EU (a $20 \%$ reduction in emissions of GHG compared to 1990 levels; increasing the share of energy from renewable sources by $20 \%$ and $20 \%$ improvement in energy efficiency).

Monitoring of emissions [8] allowed establishing the intensity of GHG emissions in energy consumption for the period 2000 to 2013 regarding Romania (fig. 2), and also the $\mathrm{CO}_{2}$ emissions' variations in intensity for the energy sector in 2000-2013 (fig. 3).

In conclusion, Romania proposed a strategy entitled "National Strategy on Climate Changes and Low Carbon Based Economic Growth".

This Strategy is developed in the context of a national vision, which must establish an economy resilient to climate change, with low carbon emissions, that will include policies and actions related to climate change, given the projected economic growth by 2050 . 


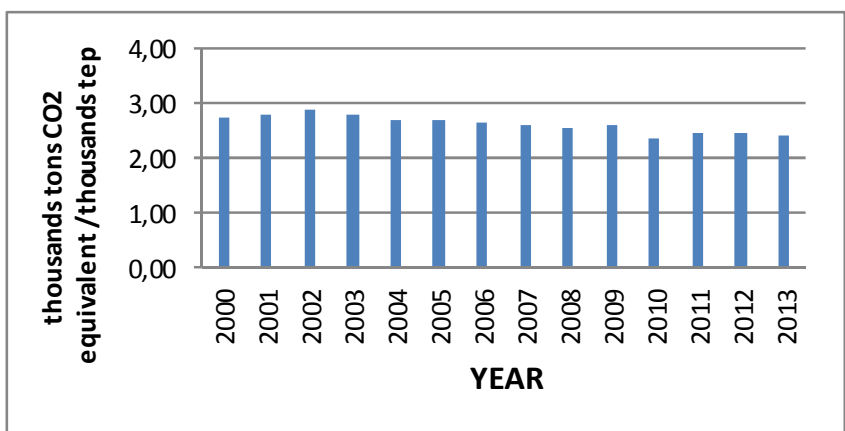

Fig. 2 Greenhouse gasses' variation in intensity for the energy consumption

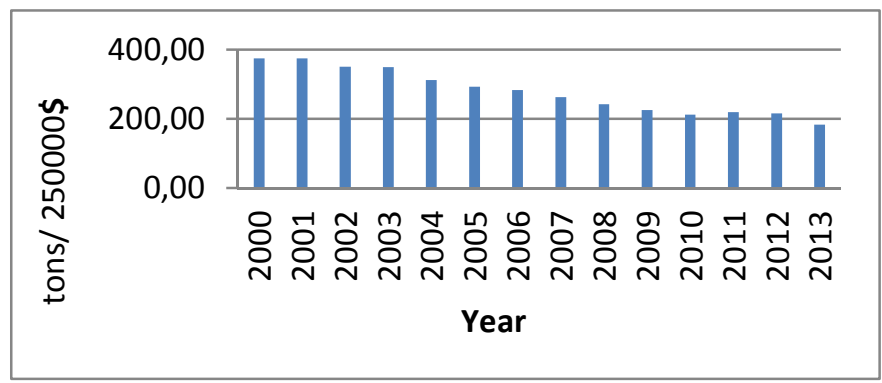

Fig. 3. $\mathrm{CO}_{2}$ emissions intensity in the energetic field

Periodical statistical surveys on the production of electrical and thermal energy, resources and consumption of electrical energy, thermal energy, fuels, fuels and lubricants, monitoring of emissions of carbon dioxide lead to a classification using various criteria $[2,6,7,8]$.

According to the the label of electricity to end customers at regulated tariffs, (Table 1), electricity supplied by Enel Energie Muntenia SA in 2015 was produced from the following sources: hydroelectric, nuclear, natural gas, coal, fuel oil, wind, biomass, solar, unconventional sources and renewable [10, 11].

For 2015, total $\mathrm{CO}_{2}$ emissions in Romania was $299.02 \mathrm{~g} /$ $\mathrm{kWh}$ of $\mathrm{CO}_{2}$ emissions resulting from electricity generation were $32.53 \mathrm{~g} / \mathrm{kWh}$. It is noted that the environmental impact is below the national average.

\section{TABLE 1. ELECTRICITY PRODUCTION SOURCES [11]}

\begin{tabular}{|c|c|c|}
\hline $\begin{array}{c}\text { The primary } \\
\text { source of } \\
\text { electricity }\end{array}$ & $\begin{array}{c}\text { Supplier } \\
\text { ultimately, } \\
\text { \% }\end{array}$ & $\begin{array}{c}\text { Romania electricity } \\
\text { production in 2015, } \\
\text { \% }\end{array}$ \\
\hline Coal & 2.93 & 26.89 \\
\hline Nuclear & 33.25 & 17.83 \\
\hline Natural gas & 1.47 & 13.52 \\
\hline Fuel oil & 0.01 & 0.06 \\
\hline $\begin{array}{c}\text { Other conventional } \\
\text { sources }\end{array}$ & 0.02 & 0.16 \\
\hline Renewable sources & 62.33 & 51.54 \\
\hline Hydroelectric & 60.79 & 27.36 \\
\hline Eolian & 1.20 & 11.03 \\
\hline Biomass & 0.08 & 0.71 \\
\hline Solar & 0.26 & 2.43 \\
\hline
\end{tabular}

Carbon dioxide, $\mathrm{CO}_{2}$, comes from flue gases resulting from combustion. A fuel must meet a number of conditions, namely, can be easily obtained from nature, is not toxic, is cheap and sufficient, so the cost of heat produced to be competitive at the time, on the energy market [3].

In Table 2 shows the development of the activities of the $\mathrm{CO}_{2}$ emission energy, namely combustion plants and refineries [12].

TABEL 2. $\mathrm{CO}_{2}$ EMISSIONS FROM THE ENERGY SECTOR ACTIVITIES, MILLION TONS [12]

\begin{tabular}{|l|l|l|l|l|}
\hline $\mathbf{C O}_{2}$ Emissions & $\mathbf{2 0 0 9}$ & $\mathbf{2 0 1 0}$ & $\mathbf{2 0 1 1}$ & $\mathbf{2 0 1 2}$ \\
\hline $\begin{array}{l}\text { Total } \mathrm{CO}_{2} \text { emissions for the } \\
\text { energy sector, including refining }\end{array}$ & 63.56 & 64.62 & 66.71 & 68.13 \\
\hline $\begin{array}{l}\text { a. Installations for the production } \\
\text { of electricity and heat }\end{array}$ & 50.11 & 51.0 & 51.8 & 53.12 \\
\hline $\begin{array}{l}\text { b. Installations for heat } \\
\text { production for industry }\end{array}$ & 5.5 & 5.63 & 5.85 & 6.0 \\
\hline $\begin{array}{l}\text { c. Other plants for production of } \\
\text { thermal energy in the residential, } \\
\text { commercial, etc. }\end{array}$ & 0.33 & 0.33 & 0.34 & 0.35 \\
\hline d. Refineries & 7.62 & 7.66 & 8.72 & 8.66 \\
\hline
\end{tabular}

\section{EXPERIMENTAL PART}

In the case of liquid petroleum fuels, the relative density of which is known, $\rho_{15}^{15}$, the fraction of carbon and hydrogen fraction can be calculated with the relationship [1]:

$$
g_{\mathrm{C}}=0.15 \rho_{15}^{15}+0.74 ; g_{\mathrm{H}}=1-g_{\mathrm{C}}
$$

The heat issued following a complete combustion with the minimum necessary air, of a unit amount of fuel is called caloric power and is a fuels characteristic. Depending on the state of aggregation for the water resulting from the combustion, the following are known:

- high caloric power $\mathrm{H}_{S}$ - when water vapor contained in the flue gases are discharged as liquid;

- low caloric power $\mathrm{H}_{i}$ - where flue gases are discharged with water vapors in the gas.

To compute the caloric power of liquid petroleum fuels one can use the following empirical relationship [1]:

$$
\mathrm{H}_{i}=46434+3169 \rho_{15}^{15}-8793\left(\rho_{15}^{15}\right)^{2}
$$

Applying relation (2) leads to results expressed in $\mathrm{kJ} / \mathrm{kg}$. The carbon dioxide emission coefficient, is used to compare the effects of combustion pollution. It is defined as the ratio between the mass of carbon dioxide resulting from combustion and the fuel's low or high caloric power. The relationship is:

$$
\varepsilon_{\mathrm{CO}_{2}}=\frac{{ }^{m} \mathrm{CO}_{2}}{\mathrm{H}}
$$

The measuring unit for carbon dioxide emission $\varepsilon_{\mathrm{CO}_{2}}$ is expressed in $\mathrm{g} / \mathrm{kWh}$ depending on the reporting, either using the high caloric power or the low one noted $\varepsilon_{\mathrm{CO}_{2}, S}$ and $\varepsilon_{\mathrm{CO}_{2}, I}$.

If the case of liquid petroleum fuels combustion, the carbon dioxide emission coefficient, considering that they have the composition only hydrogen and carbon can be calculated 
using the equations (1), (2) and (3) in the works [4] [5] computed as follows:

- $\mathrm{CO}_{2}$ emissions, relative to the lower caloric power:

$$
\varepsilon_{\mathrm{CO}_{2}, I}=\frac{2714+550 \rho_{15}^{15}}{12.898+0.88 \rho_{15}^{15}-2.442\left(\rho_{15}^{15}\right)^{2}}
$$

- $\mathrm{CO}_{2}$ emissions, relative to the higher caloric power: for liquid fuels not containing water:

$$
\varepsilon_{\mathrm{CO}_{2}, S}=\frac{2714+550 \rho_{15}^{15}}{14.529-0.061 \rho_{15}^{15}-2.442\left(\rho_{15}^{15}\right)^{2}}
$$

\section{RESULTS}

Based on the mathematical model earlier depicted, the carbon dioxide emission coefficient was calculated for three types of oil, two domestic and one imported, for which densities are known (Table 3).

TABLE 3. OIL TYPE

\begin{tabular}{|c|c|}
\hline Oil type & $\begin{array}{c}\text { Relative density (the density of } \\
\text { the liquid petroleum fuels } \\
\text { relative to water, at } \mathbf{1 5}^{\mathbf{0}} \mathbf{C} \text { ), } \\
\rho_{15}^{15}\end{array}$ \\
\hline Local light crude & 0.8475 \\
\hline Local medium crude & 0.8865 \\
\hline Impoted crude & 0.8819 \\
\hline
\end{tabular}

The obtained results are depicted in Table 4.

TABLE 4. CARBON DIOXIDE EMISSION BY COMBUSTION OF SOME LIQUEFIED PETROLEUM PRODUCTS [2]

\begin{tabular}{|c|c|c|}
\hline Crude type & $\begin{array}{c}\text { Carbon dioxide } \\
\text { emission relative } \\
\text { to the inferior } \\
\text { caloric power } \\
{\left[\mathbf{g} \mathbf{C O}_{2} / \mathbf{k W h}\right]}\end{array}$ & $\begin{array}{c}\text { Carbon dioxide } \\
\text { emission relative } \\
\text { to the superior } \\
\text { caloric power } \\
\text { [g CO } \mathbf{~} / \mathbf{k W h}]\end{array}$ \\
\hline $\begin{array}{c}\text { Local light } \\
\text { crude }\end{array}$ & 267.46 & 250.00 \\
\hline $\begin{array}{c}\text { Local medium } \\
\text { crude }\end{array}$ & 272.24 & 255.10 \\
\hline Impoted crude & 271.80 & 254.40 \\
\hline
\end{tabular}

Carbon dioxide emission analysis (Table 4) from burning hydrocarbon fluids leads to the conclusion:

$$
\begin{gathered}
\mathcal{E}_{\mathrm{CO}_{2}, \text { I,local light crude }}<\mathcal{E}_{\mathrm{CO}_{2}, \text { I,local medium crude }}< \\
\mathcal{E}_{\mathrm{CO}_{2}, \text { I, imported crude }}
\end{gathered}
$$

The lowest values of the coefficient of carbon dioxide emission are related to the combustion of hydrocarbon fluids of low density.

\section{CONCLUSION}

Research conducted in the paper used data on three types of crude oil.

From a qualitative perspective, the evaluation of the carbon dioxide emission coefficient provides a criterion for the fuel selection. Fuel with lower relative density is less polluting, whether domestic or imported.

From a quantitative perspective, knowing the amount of carbon dioxide emitted from burning of fuel allows to find the usage polluting effects.

A purchase selection criterion for a fuel, can be the carbon dioxide release.

The pollution effects quantification in case of liquid petroleum combustion can be achieved by evaluating the carbon dioxide emission coefficient.

\section{REMARKS}

$g_{i}$ - Mass fraction of component $\mathrm{i}$ in the mixture and component $\mathrm{kg} / \mathrm{kg}$ fuel

$\mathrm{H}$ - Caloric power, $\mathrm{kJ} / \mathrm{kg}, \mathrm{kJ} / \mathrm{m}^{3}{ }_{\mathrm{N}}$;

$m$ - Masa mass, kg;

${ }^{\varepsilon} \mathrm{CO}_{2}$ - carbon dioxide emission coefficient $\mathrm{g} / \mathrm{kWh}$;

$\rho_{15}^{15}$ - Relative density (density of an oil product at $15^{0} \mathrm{C}$, relative to the density of water at $15{ }^{\circ} \mathrm{C}$ )

\section{SYMBOLS}

$C$ - Carbon

$\mathrm{CO}_{2}$ - Carbon dioxide

$H$ - Hydrogen

I- Low

$S$ - High

$G H G$ - greenhouse gases

\section{REFERENCES}

[1] A.R. Cernea, D. Dobrinescu, I. Fagarasanu, A. Covaci, Thermotechnics, Ed. Diactica and Pedagogica, Bucuresti, p. 273, 1969.

[2] T. Cristescu, M. E. Stoica, Evaluation of the Emission of Carbon Dioxide in the Combustion of Biofuels and Comparison with Liquid Petroleum Products, Indian Journal of Applied Researche, vol 3, p. 28 30, October 2013.

[3] T. Cristescu, Termotechnics, Ed. University of Ploiesti, Ploieşti, p. 145, 2009.

[4] T. Cristescu, Liquefied Natural Gases and Liquefied Petroleum Gases as Complementary Sources of Energy, 5th International Conference on Energy and Environment, Bucureşti, 3-4 November, 2011.

[5] T. Cristescu, The transport and storage of liquefied gas, Ed. University of Ploiesti, , p. 258 - 259, Ploieşti 2012.

[6] T. Cristescu, M.E. Stoica, GH. Brănoiu, T. Negreanu-Pirjol, Evaluation and Comparing of the Carbon Dioxide Emission Coefficients for the Combustion of Gaseous and Liquid Hydrocarbons, Revista de chimie (Bucharest), vol 65, p.856-860, July 2014.

[7] K. Raznjevic, Thermodynamic tables and diagrams, Ed. Tehnică, Bucureşti, 1978, p. 327.

[8] www.insse.ro Institutul Naţional de Statistică, România.

[9] www.mmediu.ro/app/webroot/.../2015-08 2020_CRESC Strategia_climatica_V3.pdf.

[10] Ordin ANRE nr. 69/2009 - Regulament de etichetare a energiei electrice

[11] www.enel. ro/ro/ clienti-em.html.

[12] http://www-old.anpm.ro/files $2 / T E X T \% 20 A n e x e \% 20 H G \_N A P \_r o-$ \%20FINAL 20098183817246.pdf 